\title{
Rapid Activation Analysis of Trace Copper in Tissue Using 5.1-Minute Copper-66
}

\author{
DAVID G. KAISER ${ }^{1}$ AND W. WAYNE MEINKE \\ From the Department of Chemistry, University of Michigan, Ann Arbor, Michigan
}

Received November 16, 1962

\section{INTRODUCTION}

The activation analysis technique holds great promise for trace analysis of biological systems (1). Often in the past, however, lengthy irradiation and processing times have precluded consideration of this technique for many applications.

Activation analysis of copper in biological materials, specifically luman blood and tomato seeds, has been described by Bowen (2). The inadequacies of colorimetric, polarographic, arc spectrographic, and microbiological assays were considered before Bowen developed an activation procedure. Following a 12 -hr activation at the Harwell B. E. P. O. Reactor and a 2 -hr decay prior to chemical separation, he analyzed for the 12.8-hr copper-64.

The limit of sensitivity at saturation for 5.1-min copper-66 is much less than it is for 12.8-hr copper-64. For short irradiation times ( $5 \mathrm{~min}$ ) followed by a rapid chemical separation $(8 \mathrm{~min}$ ), however, the $5.1-\mathrm{min}$ copper-66 is about five times more sensitive than copper-64. This rapid procedure significantly reduces the total time required for each analysis as well as the interference from longer lived isotopes. Particularly in biological samples the reduction of sodium-24 permits a much greater ease of handling samples than in longer irradiations.

The tissues under investigation were rat kidney, as previous work (3) had shown copper to be present in detectable amounts. The facilities available at this laboratory permitted short irradiations in the Ford Nuclear Reactor, rapid radiochemical separation, and continuous gamma spectral analysis.

\section{EXPERIMEN'TAL}

\section{Apparatus}

Samples were irradiated in polyethylene screw-cap "rabbits" in the pneumatic tube system of the Ford Nuclear Reactor of the University

${ }^{1}$ Present address: The Upjohn Company, Kalamazoo, Michigan. 
of Michigan. This system permitted irradiations at thermal neutron fluxes of about $10^{12} n \mathrm{~cm}^{-2} \mathrm{sec}^{-1}$ (when the reactor was operating at full power of 1 megawatt) and delivery to a hood in the neighboring Michigan Memorial Phoenix Laboratory within 3 sec after the end of irradiation. Samples were then worked up chemically and were measured by a $3^{\prime \prime} \times 3^{\prime \prime} \mathrm{NaI}(\mathrm{Tl})$ crystal coupled with a special 100-channel pulse-height analyzer with duplicate memories. This equipment has been described in detail elsewhere (4-6). Similar rapid delivery systems are available now in many research centers throughout the world and many activation analyses with short-lived radioisotopes are being made (7-10).

\section{Preparation of Animals and Tissue}

Holtzman ${ }^{2}$ albino male rats weighing between 350 and 400 gm were used in this study. They were maintained on Rockland Rat Diet ${ }^{3}$ and had free access to drinking water. The kidneys were surgically removed, weighed, allowed to air-dry at room temperature for $24 \mathrm{hr}$ and then reweighed. They were placed in envelopes prepared from 4-mil thick polyethylene film, which were closed by heat sealing. The sealed sample was then irradiated in the "rabbit" along with suitable monitoring foils for a period of $5 \mathrm{~min}$ at full power.

\section{Radiochemical Separation}

While the sample was being irradiated a nickel crucible was prepared containing $10 \mathrm{mg}$ of copper carrier solution. Three sodium hydroxide pellets were added and the solution heated almost to dryness. Two minutes before the end of the irradiation, $10 \mathrm{gm}$ of sodium peroxide was added to the crucible and melted.

The irradiated sample was then fused in this melt for 1 min (CAUTION). A cover must be used on the crucible since the reaction may be quite violent. The outside of the crucible was then cooled by dipping it into a beaker of cold water and the melt made to solidify in a thin, readily dissolvable coating by manipulation of the crucible. The melt was then dissolved by immersion into $50 \mathrm{ml}$ of water and $50-70 \mathrm{ml}$ of liquid nitrogen added to cool the solution to room temperature. Thirty milliliters of concentrated hydrochloric acid was then added slowly and the solution again cooled with liquid nitrogen.

This mixture was then transferred to a $150-\mathrm{ml}$ separatory funnel containing $5 \mathrm{ml}$ of carbon tetrachloride equilibrated with $1.2 \mathrm{~N} \mathrm{HCl}$. Ten milliliters of cupferron solution $(6 \%$ aqueous) was added and shaken

\footnotetext{
${ }^{2}$ Holtzman Company, Madison 4, Wisconsin.
}

${ }^{3}$ A product of Rockland Farms, New City, N. Y.; manufactured by A. E. Staley Manufacturing Company, Chicago 27, Illinois. 
for $1 \mathrm{~min}$. The cupferron layer was back-extracted with $10 \mathrm{ml}$ of concentrated ammonium hydroxide. Copper sulfide was then precipitated by bubbling $\mathrm{H}_{2} \mathrm{~S}$ into the extract. This precipitate was collected on a filter chimney and mounted for measurement on the spectrometer. The entire procedure could be completed in $8 \mathrm{~min}$ with an average copper recovery of about $80 \%$.

\section{Activity Determination}

Linearity of the measurement system was established by the use of $\mathrm{Cs}^{137}$ and $\mathrm{Co}^{60}$ standards. Spectra were obtained in the 0-2 mev energy range as shown in Fig. 1. The amount of copper-66 was determined from

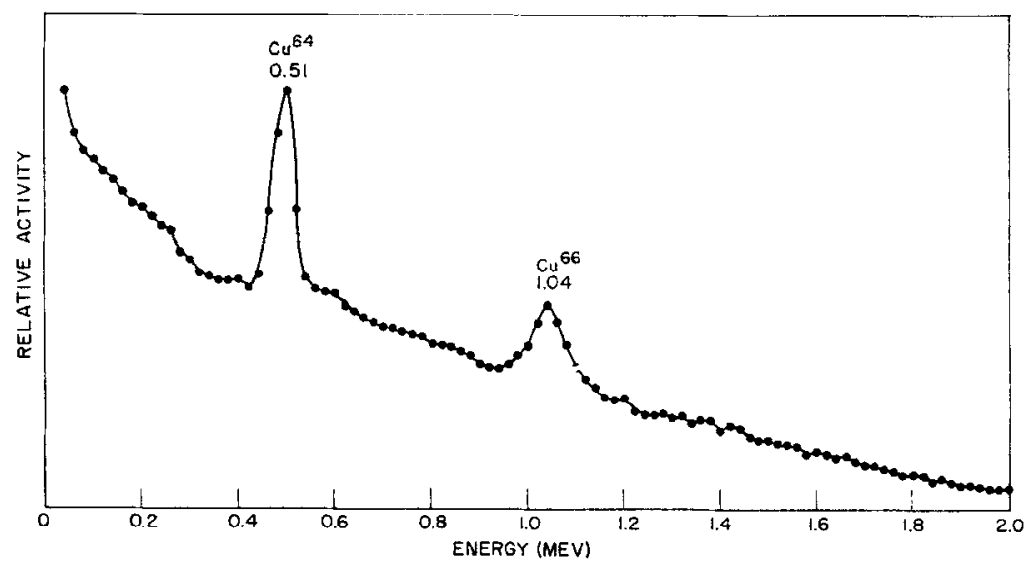

FIG. 1. Gamma-ray spectrum of copper fraction separated from rat kidney tissue. the area under the 1.04 mev photopeak while the correction for chemical yield was made by iodimetry.

\section{Chemical Yield}

The copper-iodide method described by Hillebrand, Lundell, Bright, and Hoffmann (11) was utilized for the quantitative determination of the copper yield. The sodium thiosulfate solution was standardized against potassium iodate (12).

\section{Monitoring Procedures}

Gold foils weighing between 0.1 and $0.2 \mathrm{mg}$ were wrapped in plastic envelopes and Scotch taped to the inside of the cap of the "rabbit." Following irradiation the foils were placed in test tubes and counted with a well-type scintillation counter. Comparison with other measurements made with calibrated gold foils permitted normalization of all irradiations to a neutron flux of $1 \times 10^{12}$. 


\section{RESULTS AND DISCUSSION}

By neutron activation analysis in conjunction with gamma-ray scintillation spectrometry qualitative and quantitative results may be obtained at the microgram and submicrogram levels. The quantitative results obtained in this rapid activation analysis study give the order of magnitude for copper concentration in rat kidneys and are listed in Table 1. The values reported here are slightly higher than those given

TABLE 1

Activation Analysis for Copper in Rat Kidney Tissue Using Copper-66

\begin{tabular}{ccccc}
\hline $\begin{array}{c}\text { Animal } \\
\text { No. }\end{array}$ & $\begin{array}{c}\text { Live } \\
\text { wt. } \\
(\mathbf{g m})\end{array}$ & $\begin{array}{c}\text { Fresh } \\
\text { kidney } \\
\text { wt. } \\
(\mathbf{g m})\end{array}$ & $\begin{array}{c}\text { Yield of } \\
\text { separation } \\
\text { procedure } \\
(\%)\end{array}$ & $\begin{array}{c}\text { Copper found } \\
\text { in kidneys, } \\
(\boldsymbol{\mu g}) / \mathbf{g m}^{2} \\
\text { fresh tissue }\end{array}$ \\
\hline 1 & 398.5 & 3.72 & 82.4 & 2.45 \\
2 & 388.3 & 3.17 & 88.8 & 2.22 \\
3 & 384.0 & 3.21 & 85.5 & 1.89 \\
4 & 367.5 & 2.51 & 78.7 & 2.81 \\
5 & 354.2 & 2.19 & 78.1 & 1.59 \\
\hline
\end{tabular}

"Corrected to neutron flux of $1 \times 10^{12} n \mathrm{~cm}^{-2} \mathrm{sec}^{-1}$.

by Spector (13), but of the same magnitude as presented by Guelbenzu and co-workers (14), who utilized spectroscopic methods in their studies. Individual animal variation is believed to be responsible for the range of copper values obtained.

The lower limit of detection at a thermal neutron flux of $10^{12} n \mathrm{~cm}^{-2}$ $\mathrm{sec}^{-1}$ is about $3 \times 10^{-7} \mathrm{gm}$, in contrast to the $4 \times 10^{-10} \mathrm{gm}$ reported by Bowen (2). Although analysis by means of copper-66 is thus not as sensitive as with copper-64, many problems can be more easily solved with this shorter lived isotope. Activation of many interfering elements is kept at a minimum by the short irradiation time, while in addition many analyses can be completed during the irradiation time required for a single copper-64 determination.

\section{SUMMARY}

Microgram amounts of copper have been analyzed by rapid activation analysis in rat kidney tissue. An 8-min radiochemical separation coupled with gamma-ray spectrometry permitted utilization of the 5.1-min copper-66 radioisotope. With this procedure, the lower limit of detection at a thermal neutron flux of $10^{12} n \mathrm{~cm}^{-2} \mathrm{sec}^{-1}$ was about $3 \times 10^{-7} \mathrm{gm}$ of copper.

\section{ACKNOWLEDGMENTS}

This work was supported in part by the Michigan Memorial Phoenix Project and the U. S. Atomic Energy Commission. Thanks are due Professor H. J. Gomberg, 
C. W. Ricker, and the staff of the Ford Nuclear Reactor for their help in making the irradiations.

\section{R.FFERFNCFS}

1. Loveridge, B. A., ANd Smales, A. A., in "Methods of Biochemical Analysis," (D. Glick, ed.), Vol. 5, pp. 225-272. Interscience, New York, 1957.

2. Bowes, H. J. M., Intern. J. Appl. Radiation and Isotopes 4, 214 (1959).

3. Kaiser, D. G., ANd Meinke, W. W., Talanta 3, 255 (1960).

4. Mein Ke, W. W., Nucleonics 17, No. 9, 86 (1959).

5. Mein ke, W. W., U. S. At. Energy Comm. Rept. AECU 3641, November, 1957.

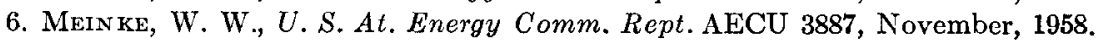

7. Meinke, W. W., "Activation Analysis Utilizing Fast Radiochemical Separations and Portable Neutron Generators," Vol. II, pp. 277-290, Proc. (IAEA and UNESCO), Copenhagen, September, 1960. IAEA, Vienna, 1961.

8. Mernke, W. W., "Techniques for Fast Radiochemistry," Proc. 1961 Intern. Conf. Modern Trends in Activation Analysis, College Station, Texas, 1961, pp. 36-40.

9. Mein Ke, W. W., "Handling and Separation of Short-Lived Radioisotopes from Research Reactors," IAEA Seminar Practical Appl. Short-Lived Radioisotopes Produced in Small Research Reactors, Vienna, November 5-9, 1962, IAEA, Vienna (in press).

10. Guins, V. P., "Reactor-Produced Short-Lived Radioisotopes Used In Neutron Activation Analysis," IAEA Seminar Practical Appl. Short-Lived Radioisotopes Produced in Small Research Reactors, Vienna, November 5-9, 1962, IAEA, Vienna (in press).

11. Hillebrand, W. F., Lundell, G. E. F., Bright, H. A., and Hoffman, J. I., "Applied Inorganic Analysis," 2nd Ed., p. 248. Wiley, New York, 1953.

12. Hamilton, L. F., and Simpson, S. G., "Talbot's Quantitative Chemical Analysis," 9th ed., p. 209. Macmillan, New York, 1946.

13. "Handbook of Biological Data" (Spector, W. S., ed.), p. 75. Saunders, Philadelphia, 1956.

14. Gueldenzu, M. D., Azcona, J. M. L., And Ruiz, A. S., Rev. Espan. Fisiol. 7, 74 (1951). 